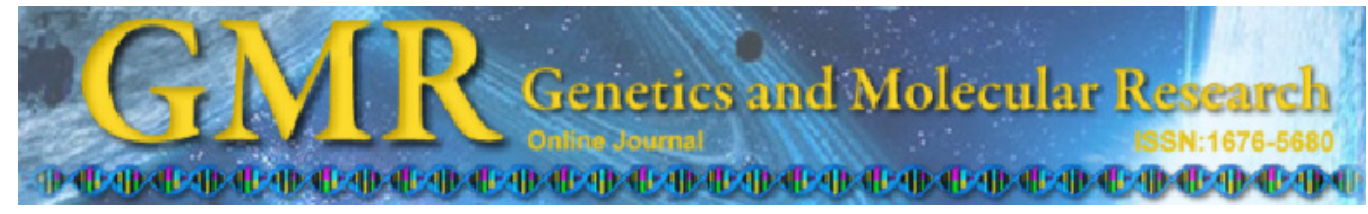

Methodology

\title{
Semi-quantitative detection of gene expression using bisbenzimide dye
}

\author{
P. Kittimongkolsuk ${ }^{1}$, T. Tencomnao ${ }^{2}$, R. Santiyanont ${ }^{2}$ \\ ${ }^{1}$ Graduate Program in Clinical Biochemistry and Molecular Medicine, \\ Faculty of Allied Health Sciences, Chulalongkorn University, \\ Bangkok, Thailand \\ ${ }^{2}$ Department of Clinical Chemistry, Center for Excellence in Omics-Nano \\ Medical Technology Development Project, \\ Faculty of Allied Health Sciences, Chulalongkorn University, Bangkok, Thailand \\ Corresponding author: R. Santiyanont \\ E-mail: rachana.s@chula.ac.th
}

Genet. Mol. Res. 10 (4): 3747-3759 (2011)

Received May 19, 2011

Accepted October 10, 2011

Published November 22, 2011

DOI http://dx.doi.org/10.4238/2011.November.22.8

\begin{abstract}
An electrochemical biosensor, using a disposable electrochemical printed chip aggregation by the bisbenzimide dye (Hoechst 33258), was used for detecting the expression of $\beta$-actin and RAGE genes. Using linear sweep voltammetry, the expression of these two genes in HeLa and HepG2 cell lines was determined based on anodic peak current, and the results were compared with conventional agarose gel electrophoresis. Total cellular RNA was reverse transcribed to complementary DNA, and amplification by PCR was carried out. Subsequently, the PCR products were subjected to detection by either electrophoresis or electrochemical biosensor. Precision of the electrochemical biosensor technique was acceptable ( $\beta$-actin: $\mathrm{CV}=$ $1.875 \%$ for $10^{4}$ copies and $4.684 \%$ for $10^{9}$ copies; RAGE: $\mathrm{CV}=2.253 \%$ for $10^{9}$ copies, and $3.743 \%$ for 10 copies). In the electrochemical biosensor technique, the PCR products were measured in the same run with various concentrations of standards, and copy numbers of $\beta$-actin gene were interpolated from a standard curve. Copy numbers of the
\end{abstract}


$\beta$-actin gene were then compared between the two techniques. At the $95 \%$ confidence limit, the two methods had no significant differences and were significantly correlated $(\mathrm{y}=-40383.0623+1.0233 \mathrm{x} ; \mathrm{P}>0.10)$. The electrochemical biosensor method was more sensitive than the conventional electrophoresis method because it could detect as low as 10 copies of the RAGE gene. The conventional electrophoresis method detected the RAGE gene at concentrations of at least $10^{4}$ copies, and the linearity for semi-quantitative measurement was in the range of $10^{6}-10^{9}$ copies. When the electrochemical biosensor was applied to detect the RAGE gene expression in both cell types, we found that HeLa cells expressed the RAGE gene about 2-fold higher than in HepG2 cells (relative value of $0.000905 v s 0.0004670$ ). Therefore, this study suggests the potential modification of the electrochemical biosensor with the use of bisbenzimide dye (Hoechst 33258) for detecting gene expression.

Key words: Electrochemical biosensor; DEP chip; Hoechst 33258; Gene expression; RAGE; $\beta$-actin

\section{INTRODUCTION}

Nowadays, there are many techniques for detecting a nucleic acid. The conventional technique is polymerase chain reaction (PCR) used together with agarose gel electrophoresis. Gel electrophoresis is not only time-consuming, but also sensitive to many factors such as agarose type, buffer and voltage. In fact, sensitivity of agarose gel electrophoresis may not be suitable for detecting a minute amount of PCR product. As a result, a real-time PCR has been developed for faster detection, greater sensitivity and quantitative assay since it can detect PCR products in real-time during the exponential phase. Therefore, this particular technique has been applied for a decade for determining certain gene expression profiles in several chronic degenerative diseases such as diabetes (Nagaev and Smith, 2001) and cancer (Bernard and Wittwer, 2002). However, the use of the real-time PCR approach has been limited because of various requirements including high-cost specific instruments and chemicals as well as skillful operators. Recently, a biosensor technique has been introduced for detection of nucleic acids, enzymes, antibodies and other biomarkers. Fundamentally, a electrochemical biosensor consists of two main parts, which are the recognition part specific to target analytes such as nucleic acids, enzymes and antibodies, and a transducer capable of converting a specific signal to an electrical signal (Scheller, et al., 2001). For the electrochemical-based detection technique, fluorescent dye such as Hoechst 33258 has been popularly used to detect DNA or to track DNA replication (Latt and Stetten, 1976). The Hoechst 33258 dye functions as a DNA intercalator that binds effectively to a minor groove of double-stranded DNA at its A-T rich region (Embrey et al., 1993). In its free form, this dye is oxidized to provide an electron to the electrode of the electrochemical biosensor to produce the electrochemical signal, which can be measured as an anodic current peak. The anodic current peak is measured via linear sweep voltammetry (LSV) (Sufen et al., 2002). In contrast, when Hoechst 33258 binds to DNA in the solution, the electrochemical signal or anodic current peak is inversely proportional to DNA concentration. This particular dye has commonly been used because the effect of DNA aggre- 
gation by this molecule is better than the others (Kobayashi et al., 2004). The electrochemical biosensor using Hoechst 33258 has been applied for analysis of DNA in several areas including detection of bovine constituents in feedstuff (Chaumpluk et al., 2006), detection of single nucleotide polymorphisms (SNPs) of clinically important alleles using a disposable electrochemical printed (DEP) chip (Ahmed et al., 2007) and identification of meat species using DEP chips with a loop mediated isothermal amplification technique (Ahmed et al., 2010). The electrochemical biosensor aggregation with Hoechst 33258 is easy to use, inexpensive and less time-consuming because it eliminates the immobilization step and reduces expense for specific probes. Also, it increases efficiency of detection when used in combination with PCR.

In this study, we modified the label-free electrochemical biosensor using a DEP chip, Hoechst 33258, and LSV for semi-quantitative determination of gene expression. The technique was applied to detect such commonly expressed genes as $\beta$-actin and compare both correlation and efficiency with a conventional agarose gel technique. Finally, this technique was applied to detect a gene of interest, receptor for advanced glycation endproducts (RAGE). From a clinical viewpoint, this particular receptor has been reported to cause pathological effects in many types of chronic degenerative diseases upon binding to certain types of specific ligands (Schmidt et al., 2001; Stern et al., 2002). Since human liver carcinoma (HepG2) and human cervical cancer (HeLa) cell lines have previously been demonstrated to express the RAGE gene (Zhang et al., 2007), they were used as in vitro models for determining RAGE gene expression in a semi-quantitative manner in the present study. The degree of gene expression in both cell lines was also compared with regard to their relative copy numbers.

\section{MATERIAL AND METHODS}

\section{Cell culture}

HeLa and HepG2 cell lines were cultured in $25-\mathrm{cm}^{2}$ flasks (SPL Life Sciences, Gyeonggi-Do, Korea) with Dulbecco's modified Eagle's medium (DMEM) containing 10\% fetal bovine serum (FBS) (Hyclone Thermo Scientific, Logan, UT, USA) at $37^{\circ} \mathrm{C}$ under $5 \% \mathrm{CO}_{2}$.

\section{Total RNA extraction and semi-quantitative reverse transcriptase-PCR (RT-PCR)}

After HeLa and HepG2 cells were seeded in six-well plates (Corning Life Sciences, Corning, NY, USA) at a cell density of $1 \times 10^{6}$ cells/well in complete growth medium and incubated overnight at $37^{\circ} \mathrm{C}$ under $5 \% \mathrm{CO}_{2}$, total RNA was extracted using the NucleoSpin ${ }^{\circledR}$ RNA II kit (Macherey-Nagel, Düren, Germany) according to manufacturer instructions. The amount of RNA was determined by absorbance at $260 \mathrm{~nm}$. Then, total RNA was reverse transcribed into complementary DNA (cDNA) in a total volume of $20 \mu \mathrm{L}$ per reaction using the Verso $^{\mathrm{TM}}$ cDNA synthesis kit (ABgene Ltd, Epsom, UK) at $42^{\circ} \mathrm{C}$ for 30 min for 1 cycle and inactivation at $95^{\circ} \mathrm{C}$ for $2 \mathrm{~min}$ for 1 cycle. In the RT reactions, both $300 \mathrm{ng}$ and $1200 \mathrm{ng}$ of total RNA were added into the $20-\mu \mathrm{L}$ reaction tubes, thus giving rise to final concentrations of total RNA, 15 and $60 \mathrm{ng} / \mu \mathrm{L}$, respectively. Assuming that $100 \%$ cDNA conversion efficiency for RT was achieved, $5 \mu \mathrm{L}$ of the RT reaction corresponding to 75 and $300 \mathrm{ng}$ cDNA was used 
as a template for PCR.

Since interference due to non-specific PCR products can occur, thus resulting in a misinterpretation of DNA detection by the electrochemical biosensor, the newly designed specific primers (RAGE forward: 5'-GTGGGGACATGTGTGTCAGAGGGAA-3' and RAGE reverse: 5'-TGAGGAGAGGGCTGGGCAGGGACT-3' were of great importance for this study. However, specific primers for detecting the mRNA expression of our studied housekeeping gene ( $\beta$-actin forward: 5'-ACGGGTCACCCACACTGTGC-3' and $\beta$-actin reverse: 5'-CTAGAAGCATTTGCGGTGGACGATG-3') were based on a previous report (Fisker et al., 2004). The expected PCR products were 383 bp for RAGE and 656 bp for $\beta$-actin. After the RT step, PCR amplification was performed for 30 cycles using a PTC-200 DNA Engine (GMI, Ramsey, MN, USA) in a $50-\mu \mathrm{L}$ reaction mixture. After initial denaturation at $95^{\circ} \mathrm{C}$ for $5 \mathrm{~min}$, each cycle of PCR consisted of a $30 \mathrm{~s}$ denaturation at $95^{\circ} \mathrm{C}$, a $30 \mathrm{~s}$ annealing at $65^{\circ} \mathrm{C}$ for RAGE and $58^{\circ} \mathrm{C}$ for $\beta$-actin, and a $30 \mathrm{~s}$ extension at $72^{\circ} \mathrm{C}$. The final extension at $95^{\circ} \mathrm{C}$ for $5 \mathrm{~min}$ and $15 \mathrm{~min}$ was carried out for RAGE and $\beta$-actin amplification, respectively. For the amplification reaction, a PCR mixture composed of $5 \mu \mathrm{L}$ of the above RT reaction mixture, 10X Taq buffer, $1.0 \mathrm{mM} \mathrm{MgCl}$ for RAGE or $1.5 \mathrm{mM} \mathrm{MgCl}_{2}$ for $\beta$-actin, $10 \mathrm{mM}$ dNTPs, $10 \mu \mathrm{M}$ primers and 1.25 U Taq DNA polymerase (Fermentas, Burlington, ON, Canada) was used.

\section{Establishment of standard curves for RAGE and $\beta$-actin genes}

Briefly, plasmid DNA constructs were previously made using two commercial vectors, pcDNA3.1/V5-His TOPO ${ }^{\circledR}$ TA vector (Invitrogen, Carlsbad, CA, USA) and pGEM-T Easy $^{\circledR}$ vector (Promega, Madison, WI, USA) for RAGE and $\beta$-actin DNA fragments, respectively. The 6764-bp plasmid construct, referred to as pcDNA3.1/V5-His TOPO ${ }^{\circledR}$ TA-RAGE, was made as described elsewhere (Lertwittayapon, 2010), while the 3671-bp pGEM-T Easy ${ }^{\circledR}$ $\beta$-actin construct was provided as a gift by Varaporn Rakkhitawatthana (Graduate Program in Clinical Biochemistry and Molecular Medicine, Faculty of Allied Health Sciences, Chulalongkorn University, Bangkok, Thailand). Corresponding plasmid constructs were extracted from bacteria by PureLink ${ }^{\mathrm{TM}}$ HiPure Plasmid Maxiprep kit (Invitrogen). Each extracted plasmid DNA was used for making at least 5 concentrations of the standard curve. In particular, RAGE standards consisted of $10^{9}, 10^{7}, 10^{5}, 10^{3}$, and 10 copies, and $\beta$-actin standards composed of $10^{9}, 10^{8}, 10^{7}, 10^{6}, 10^{5}$, and $10^{4}$ copies to cover the applicable concentrations of samples. Several standard concentrations were used for creating standard curves with regard to agarose gel electrophoresis and electrochemical biosensor methods.

\section{Electrochemical DNA biosensor}

A $200-\mu \mathrm{M}$ stock solution of Hoechst 33258 [2-(4-hydroxyphenyl)-5-(4-methyl1-piperazinyl)-2,5-bi(1H-benzimidazole) from Sigma-Aldrich (St. Louis, MO, USA) was prepared by dissolving Hoechst 33258 in distilled water with high purity, which was filtered through a $0.2-\mu \mathrm{m}$ syringe filter (Corning Life Sciences). The Hoechst 33258 solution was then divided into small aliquots and kept in the dark at $-20^{\circ} \mathrm{C}$. The Hoechst 33258 stock solution was diluted in $50 \mathrm{mM}$ phosphate buffer solution, $\mathrm{pH} 7.4$, just before use, and then mixed with fresh PCR products to reach the final Hoechst 33258 concentration of $20 \mu \mathrm{M}$. The mixture was 
incubated in a heat box at $37^{\circ} \mathrm{C}$ for $25 \mathrm{~s}$, and then $20 \mu \mathrm{L}$ of the reaction mixture was loaded on the working electrode of the DEP chip (Biodevice Technology, Ishikawa, Japan) (Figure 1). In particular, EP-N chips consisting of a round carbon electrode with an area of $2.64 \mathrm{~mm}^{2}$, $\mathrm{Ag} / \mathrm{AgCl}$ reference electrode and a counter electrode were utilized for this study. The detection system consisted of a multichannel DNA chip tester (measurement program) using LSV with a scan rate of $100 \mathrm{mV} / \mathrm{s}$, initial electric potential of $1000 \mathrm{mV}$ and final electric potential of $1000 \mathrm{mV}$. The changes in anodic current were recorded, and anodic current peak was used for further calculations.

\section{Round working electrode}
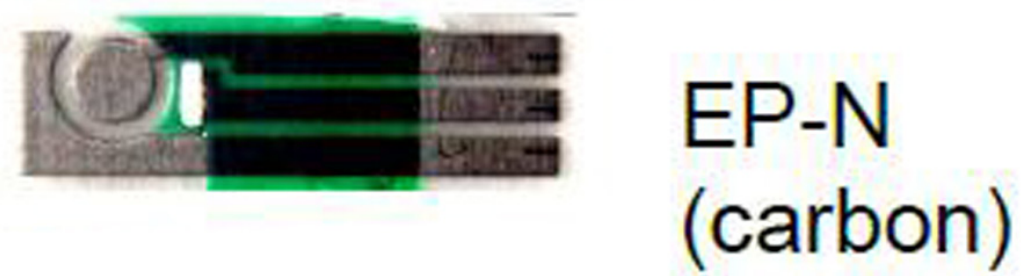

Figure 1. Appearance of disposable electrochemical printed (DEP) chips, round working electrode type EP-N (Biodevice Technology, Ishikawa, Japan).

\section{Electrophoresis detection of DNA}

PCR products of RAGE and $\beta$-actin from the same tubes, which were analyzed by electrochemical biosensor, were loaded on $2 \%$ agarose gel (Research Organics, Inc., Cleveland, OH, USA) and run in $1 \mathrm{X}$ TAE buffer with $90 \mathrm{~V}$ for $35 \mathrm{~min}$. The agarose gel was stained with ethidium bromide, and specific bands were visualized and measured using a Gel Documentation system (Syngene, Cambridge, UK).

\section{RESULTS}

\section{Standard curves of $\beta$-actin and RAGE genes}

Standard curves of $\beta$-actin and RAGE genes were created for the electrochemical biosensor method using DEP chip aggregation by Hoechst 33258, and for agarose gel electrophoresis. Using agarose gel electrophoresis to evaluate the success of the PCR approach, as varying concentrations of plasmid constructs containing either $\beta$-actin or RAGE fragments were used as templates, the results showed that the lowest detectable concentration was $10^{4}$ copies for $\beta$-actin (Figure 2A) and RAGE (Figure 2B). In agarose gel electrophoresis, band intensities of $\beta$-actin gene expressed in HeLa and HepG2 cells were revealed when analyzing cDNA concentrations of $75 \mathrm{ng}$ (Figure 3A) and $300 \mathrm{ng}$ (Figure 3B). Standard curves from the electrophoresis method were plotted with respect to DNA concentrations (log copy numbers) used as PCR templates versus band densities derived from electrophoretogram for $\beta$-actin (Figure 4A) and RAGE (Figure 4B). 

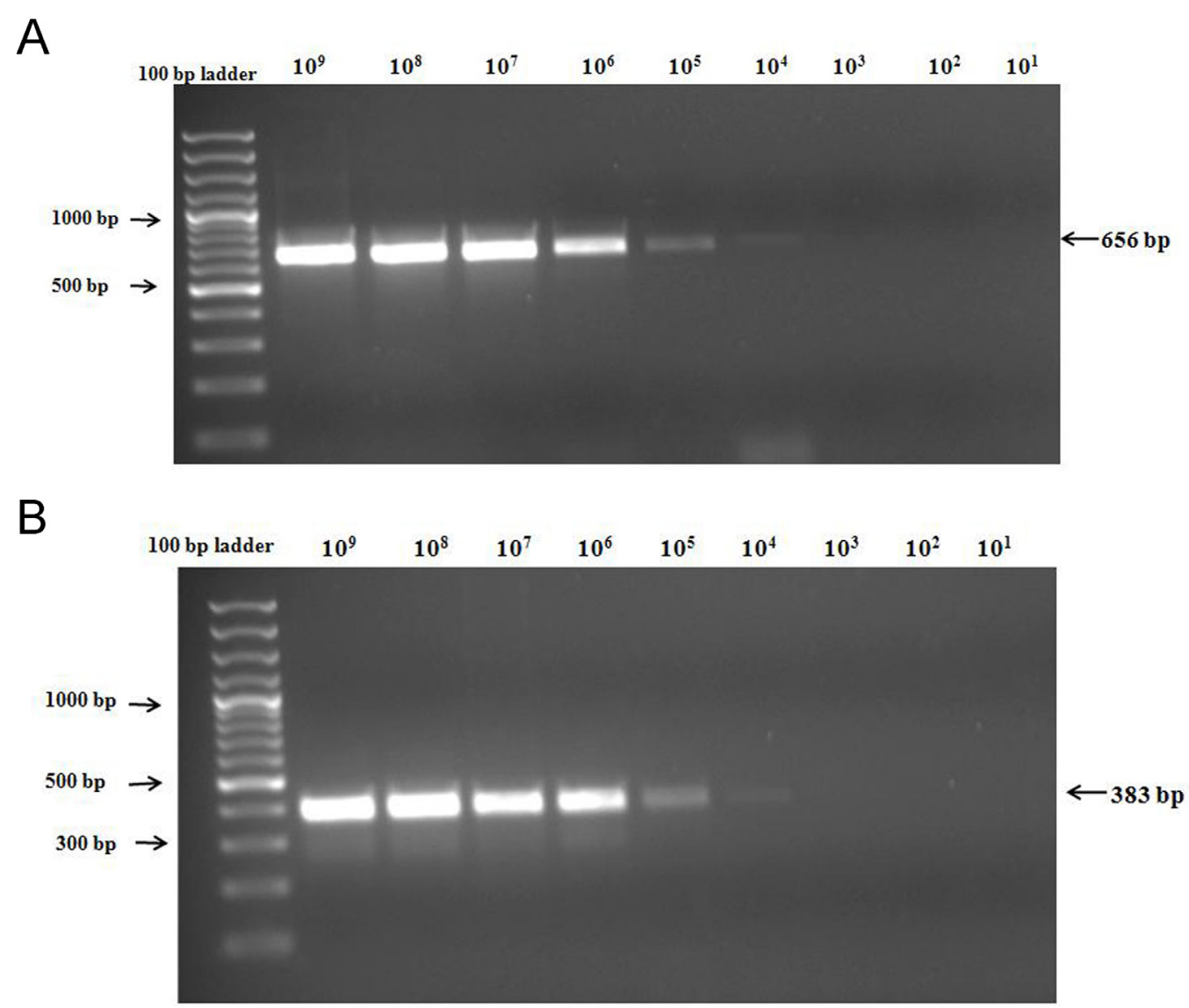

Figure 2. Sensitivity of agarose gel electrophoresis for detecting PCR products derived from various concentrations of DNA templates for $\beta$-actin (A) and RAGE (B).

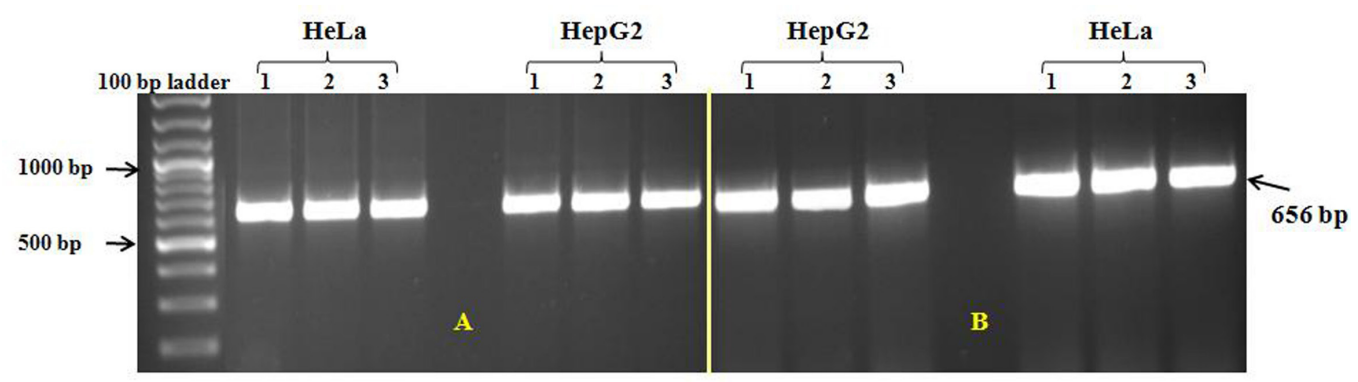

Figure 3. Specific band intensities of $\beta$-actin gene expressed in HeLa and HepG2 cells as analyzed using RT-PCR and tested on agarose gel electrophoresis. PCR reactions were based on cDNA concentrations of $75 \mathrm{ng}(\mathbf{A})$ and 300 $\mathrm{ng}(\mathbf{B})$ as templates. The experiments were done in triplicate. 
For the electrochemical biosensor, since the current was dependent on free Hoechst 33258 molecules in the mixture, the current peak was inversely proportional to DNA concentration. A standard curve of $\beta$-actin gene was plotted between log copy numbers and anodic current peaks and a linear line was drawn $\left(y=5.8249-0.3523 \mathrm{x} ; \mathrm{R}^{2}=0.9783\right)$ (Figure 5A). Therefore, after measuring samples using the electrochemical biosensor, copy numbers of $\beta$-actin could be determined according to the established standard curve. Likewise, a standard curve for the RAGE gene was created, and a regression equation was developed ( $\mathrm{y}=7.1590$ $0.2270 \mathrm{x} ; \mathrm{R}^{2}=0.9937$ ) (Figure 5B).

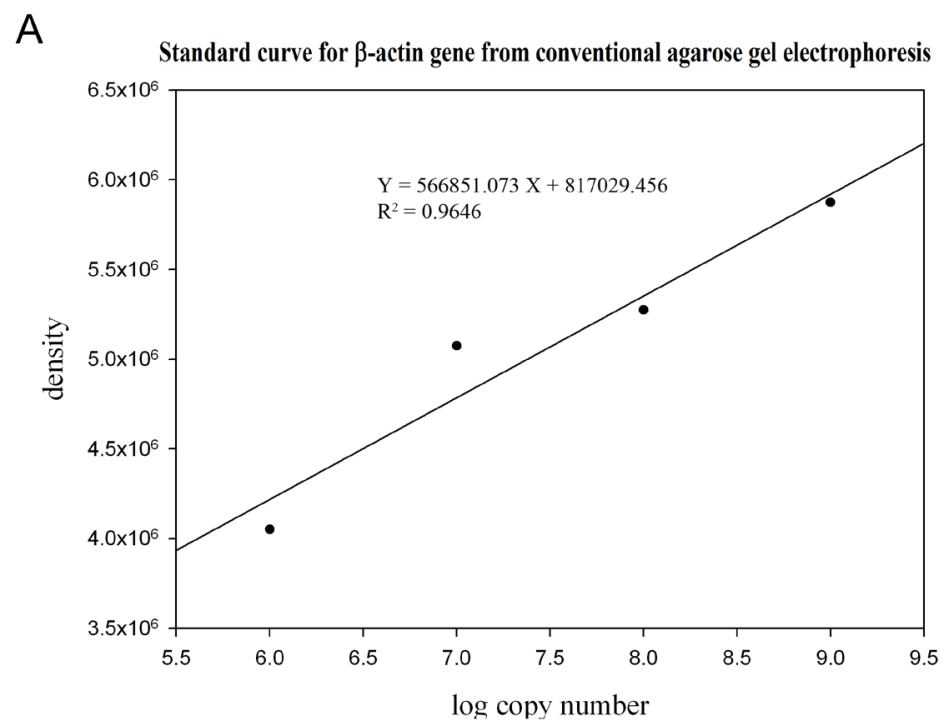

B

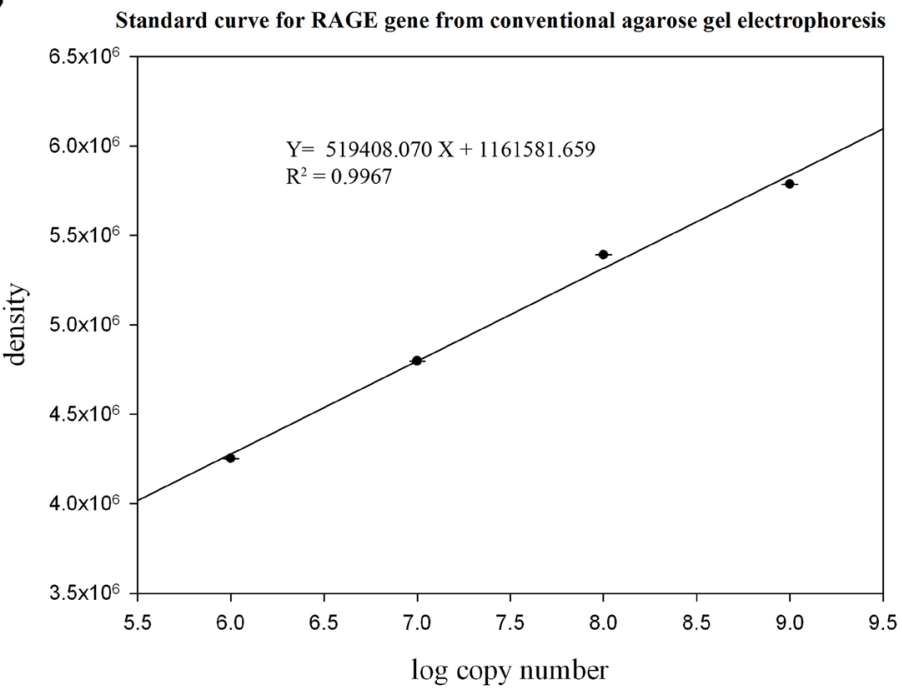

Figure 4. Standard curves of the electrophoresis method plotted with respect to DNA concentrations (log copy numbers) used as PCR templates versus band densities from electrophoretograms for $\beta$-actin (A) and RAGE (B). 
A

Standard curve for $\beta$-actin gene

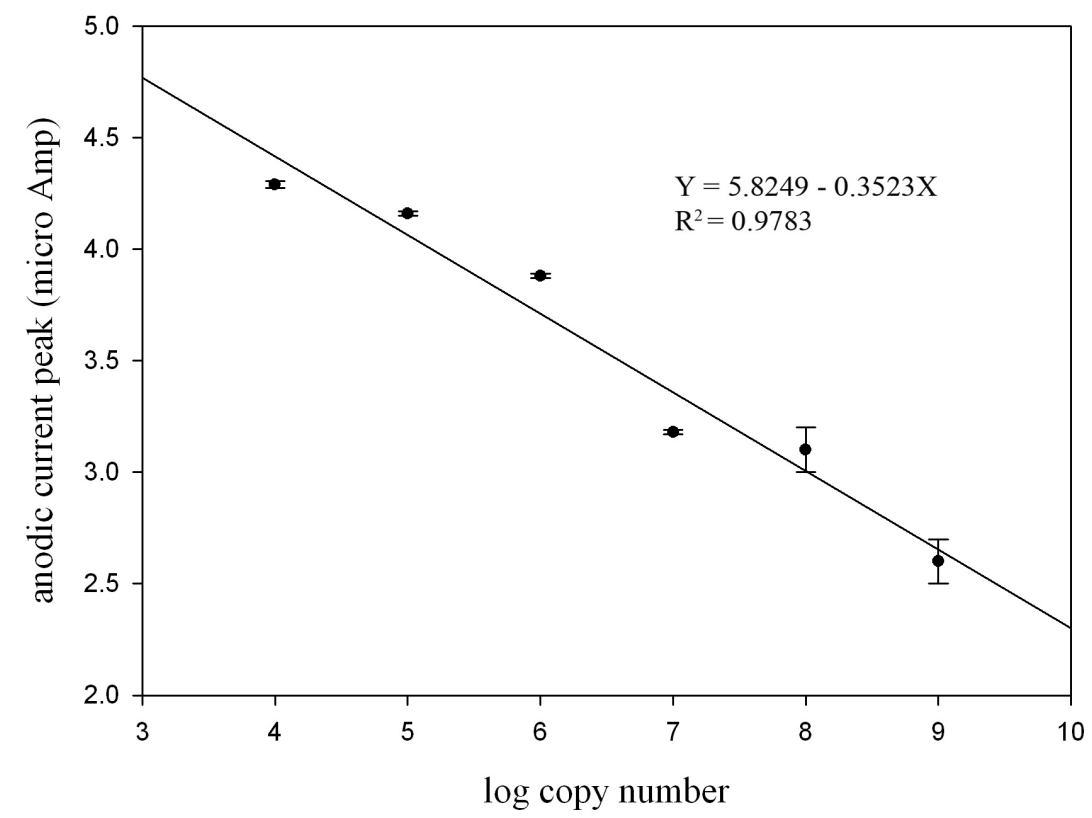

B

Standard curve for RAGE gene

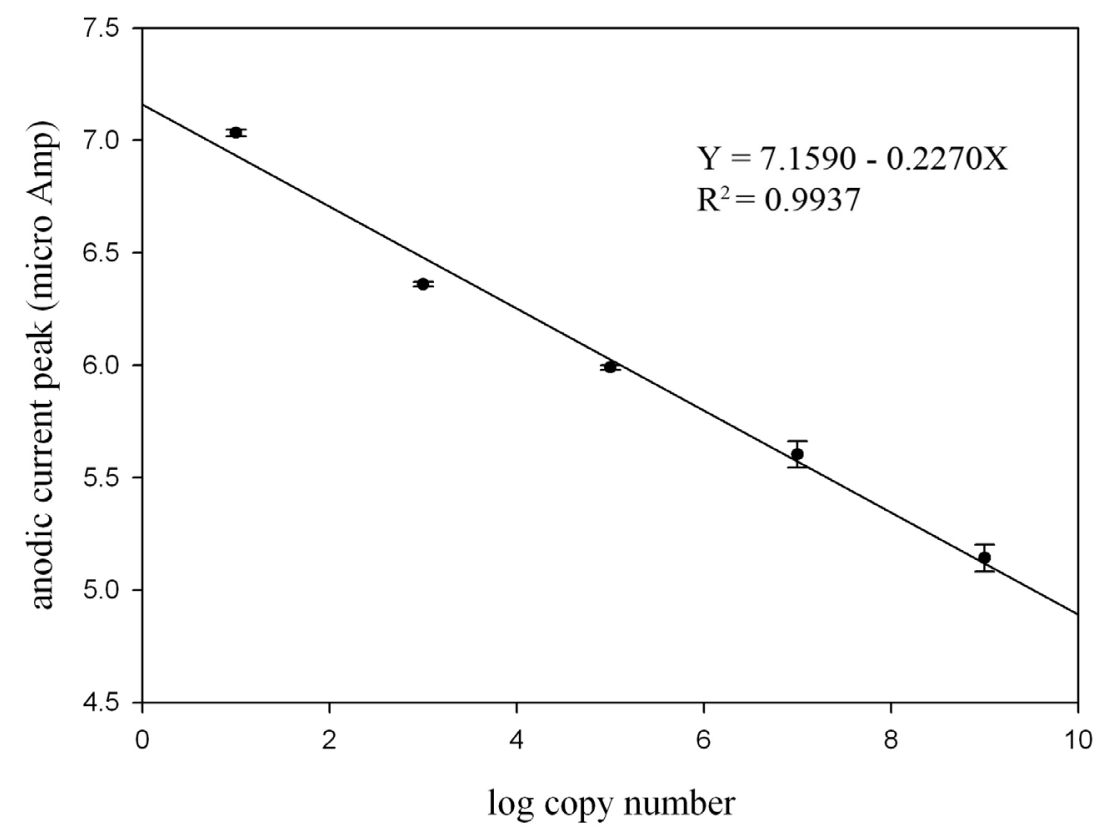

Figure 5. Standard curves of the electrochemical biosensor method plotted with respect to DNA concentrations (log copy numbers) used as PCR templates versus anodic current peaks from electrochemical biosensor for $\beta$-actin (A) and RAGE (B). 


\section{Precision of the electrochemical biosensor method}

$\beta$-actin DNA standards at a low level $\left(10^{4}\right.$ copies $)$ and high level $\left(10^{9}\right.$ copies $)$ were measured 10 times (data not shown), and the coefficient of variation $(\% \mathrm{CV})$ was calculated to be $4.684 \%$ and $1.875 \%$ for the high and low levels, respectively.

RAGE DNA standards at a low level (10 copies) and high level $\left(10^{9}\right.$ copies $)$ were measured 10 times (data not shown), and $\% \mathrm{CV}$ was calculated to be $2.253 \%$ and $3.743 \%$ for the high and low levels, respectively.

\section{Comparison between electrochemical DNA biosensor and agarose gel electrophoresis}

The copy numbers of the $\beta$-actin gene were determined from both the electrochemical biosensor and agarose gel electrophoresis. The concentrations of $\beta$-actin gene copy numbers for the two techniques were compared (Table 1).

\begin{tabular}{|c|c|c|c|c|c|c|}
\hline \multirow[t]{3}{*}{ Measurement } & \multicolumn{6}{|c|}{75 ng of cDNA } \\
\hline & \multicolumn{3}{|c|}{ HeLa cell line } & \multicolumn{3}{|c|}{ HepG2 cell line } \\
\hline & No. 1 & No. 2 & No. 3 & No. 1 & No. 2 & No. 3 \\
\hline Anodic peak $(\mu \mathrm{A})$ & 3.52 & 3.51 & 3.52 & 3.54 & 3.54 & 3.55 \\
\hline Electrochemical biosensor & $3,467,369$ & $3,715,352$ & $3,467,369$ & $3,090,295$ & $3,090,295$ & $2,884,032$ \\
\hline Agarose gel electrophoresis & $3,467,369$ & $3,548,134$ & $3,467,369$ & $3,019,952$ & $3,019,952$ & $3,019,952$ \\
\hline \multirow[t]{3}{*}{ Measurement } & \multicolumn{6}{|c|}{$300 \mathrm{ng}$ of cDNA } \\
\hline & \multicolumn{3}{|c|}{ HeLa cell line } & \multicolumn{3}{|c|}{ HepG2 cell line } \\
\hline & No. 1 & No. 2 & No. 3 & No. 1 & No. 2 & No. 3 \\
\hline Anodic peak $(\mu \mathrm{A})$ & 2.74 & 2.74 & 2.75 & 2.76 & 2.76 & 2.77 \\
\hline Electrochemical biosensor & $575,439,937$ & $575,439,937$ & $537,031,796$ & $501,187,234$ & $501,187,234$ & $467,735,141$ \\
\hline Agarose gel electrophoresis & $562,341,325$ & $562,341,325$ & $549,540,870$ & $489,778,819$ & $501,187,234$ & $489,778,819$ \\
\hline
\end{tabular}

Statistical method was used to assess the correlation between measurements of the two methods. The equation based on Passing-Bablok regression was $y=-40383.0623+$ $1.0233 \mathrm{x}$, and the slope fitted with a 95\% confidence limit of 0.9771-1.1834 (Figure 6). This demonstrated that the electrochemical biosensor correlated well with the conventional agarose gel electrophoresis.

\section{Application for detection of gene of interest}

Electrochemical biosensor aggregation with Hoechst 33258 was applied to detect the RAGE gene from HeLa and HepG2 cells, using cDNA from the same tube of $\beta$-actin gene amplification. The copy number of the RAGE gene was interpolated from a standard curve, and RAGE gene expression was calculated in relation to the $\beta$-actin gene (Table 2).

When different concentrations of cDNA were used for subsequent PCR amplification, the relative values or estimated RAGE concentrations from HeLa and HepG2 were analyzed by paired $t$-test. The result showed no statistically significant difference between RAGE gene copy numbers in each cell line when either $75 \mathrm{ng}$ or $300 \mathrm{ng}$ of cDNA was used (P = 
0.761). The average RAGE gene expression levels of HeLa and HepG2 were 0.0009051 and 0.0004670 , respectively. Therefore, HeLa cells expressed the RAGE gene about 2-fold higher than HepG2 cells did.

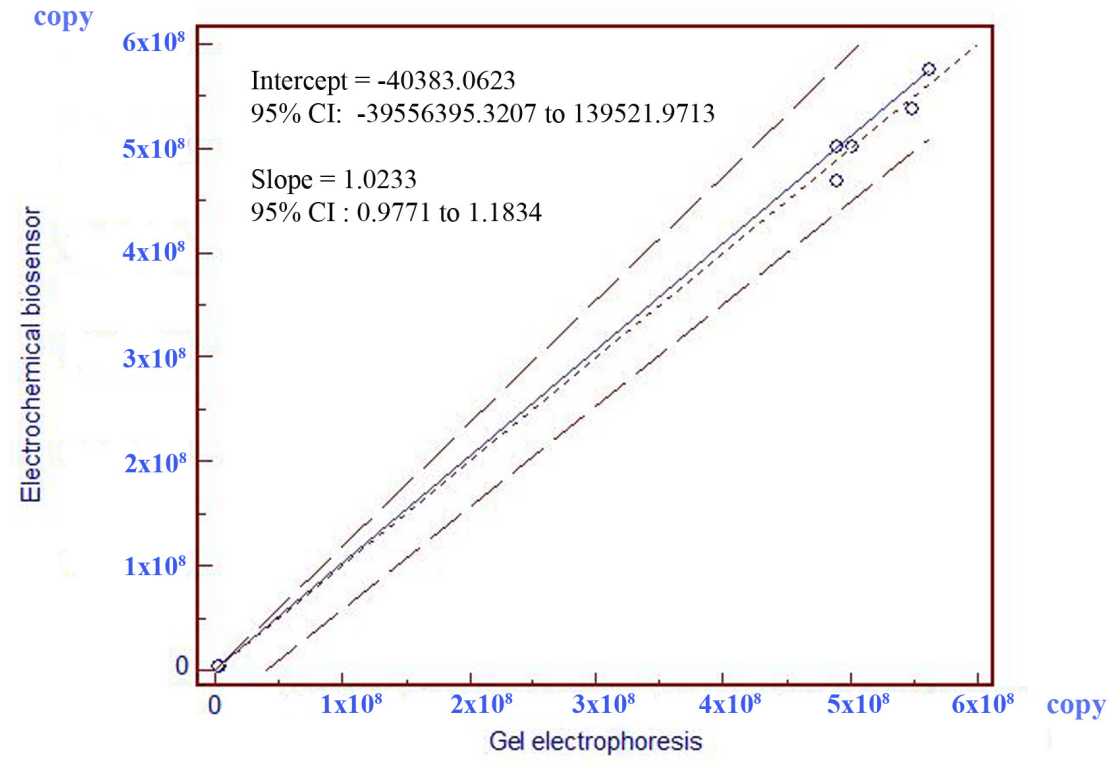

Figure 6. Correlation between the electrochemical biosensor and the conventional agarose gel electrophoressis for detecting $\beta$-actin DNA using Passing-Bablok regression analysis. Sensitivity of agarose gel electrophoresis for detecting $\beta$-actin PCR product derived from various concentrations of DNA templates. The lowest concentration of $\beta$-actin DNA that could be detected by agarose gel electrophoresis was $10^{4}$ copies.

\begin{tabular}{|c|c|c|c|c|c|c|}
\hline \multirow[t]{3}{*}{ Measurement } & \multicolumn{6}{|c|}{75 ng of cDNA } \\
\hline & \multicolumn{3}{|c|}{ HeLa cell line } & \multicolumn{3}{|c|}{ HepG2 cell line } \\
\hline & No. 1 & No. 2 & No. 3 & No. 1 & No. 2 & No. 3 \\
\hline \multicolumn{7}{|l|}{ Anodic peak $(\mu \mathrm{A})$} \\
\hline RAGE gene & 6.36 & 6.36 & 6.37 & 6.44 & 6.44 & 6.45 \\
\hline$\beta$-actin gene & 3.52 & 3.51 & 3.52 & 3.54 & 3.54 & 3.55 \\
\hline \multicolumn{7}{|l|}{ Copy number } \\
\hline RAGE gene & 3,311 & 3,311 & 3,020 & 1,479 & 1,479 & 1,318 \\
\hline$\beta$-actin gene & $3,467,369$ & $3,715,352$ & $3,467,369$ & $3,090,295$ & $3,090,295$ & $2,884,032$ \\
\hline Estimated RAGE gene concentration & 0.0009549 & 0.0008912 & 0.0008710 & 0.0004786 & 0.0004786 & 0.0004570 \\
\hline \multirow[t]{3}{*}{ Measurement } & \multicolumn{6}{|c|}{$300 \mathrm{ng}$ of cDNA } \\
\hline & \multicolumn{3}{|c|}{ HeLa cell line } & \multicolumn{3}{|c|}{ HepG2 cell line } \\
\hline & No. 1 & No. 2 & No. 3 & No. 1 & No. 2 & No. 3 \\
\hline \multicolumn{7}{|l|}{ Anodic peak $(\mu \mathrm{A})$} \\
\hline RAGE gene & 5.86 & 5.86 & 5.87 & 5.94 & 5.95 & 5.96 \\
\hline$\beta$-actin gene & 3.52 & 3.51 & 3.52 & 3.54 & 3.54 & 3.55 \\
\hline \multicolumn{7}{|l|}{ Copy number } \\
\hline RAGE gene & 524,807 & 524,807 & 478,630 & 234,423 & 257,040 & 190,546 \\
\hline$\beta$-actin gene & $575,439,937$ & $575,439,937$ & $537,031,796$ & $501,187,234$ & $501,187,234$ & $467,735,141$ \\
\hline Estimated RAGE gene concentration & 0.0009120 & 0.0009120 & 0.0008913 & 0.0004677 & 0.0005129 & 0.0004074 \\
\hline
\end{tabular}


When the same samples of RAGE DNA at various concentrations for PCR were measured with the electrophoresis method (Figures 4A and 4B), the results demonstrated that the electrochemical biosensor was more sensitive than the conventional method. Particularly, the lowest detection concentration of $10^{4}$ copies for the RAGE gene was achieved using the electrophoresis method (Figure 2B), whereas the lowest one was as low as 10 copies for the biosensor method (Figure 5B).

The expression of the RAGE gene from HeLa and HepG2 cells could be found when using cDNA at a concentration of $300 \mathrm{ng}$ for PCR (Figure 7B), but not at $75 \mathrm{ng}$ (Figure 7A). In addition, the RAGE gene was expressed more abundantly in HeLa than in HepG2 cells (Figure 7B).

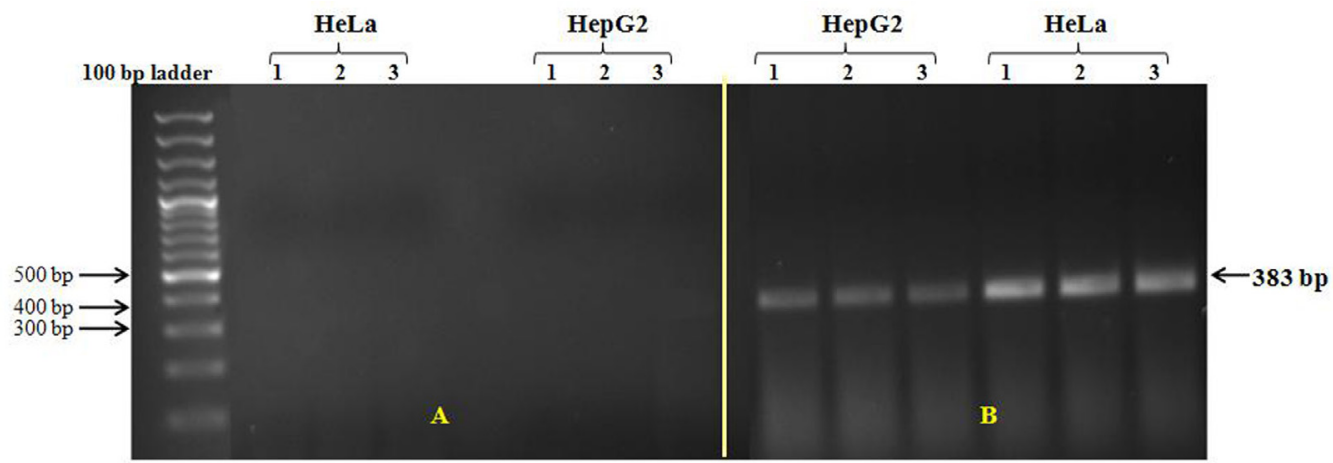

Figure 7. Specific band intensities of RAGE gene expressed in HeLa and HepG2 cells as analyzed using RT-PCR and tested on agarose gel electrophoresis. PCR reactions were based on cDNA concentrations of $75 \mathrm{ng}$ (A) and 300 ng (B) as templates. The experiments were done in triplicate.

\section{DISCUSSION}

An electrochemical biosensor based on the use of Hoechst 33258 is fast and easy to perform because the probe immobilization step is not required. There was a previous report of using an electrochemical biosensor for detecting gene expression in plant tissues, but the assay principle was based on enzyme-linked DNA hybridization assay (Horaková-Brazdilova et al., 2008). The electrochemical biosensor using Hoechst 33258 has been applied to detect bovine constituents in feedstuff (Chaumpluk et al., 2006), but that particular investigation did not provide any related information with regard to gene expression. In this study, electrochemical biosensor aggregation with Hoechst 33258 was applied to detect gene expression of the highly expressed gene, $\beta$-actin, and compared with the conventional agarose gel electrophoresis method. The technique was then applied to detect the gene of interest, which was less abundantly expressed, the RAGE gene, from HeLa and HepG2 cell lines. The result from this study demonstrated that the electrochemical biosensor is faster than the conventional electrophoresis method because it can shorten the time required for agarose gel electrophoresis and ethidium bromide staining. Specifically, the overall time required to detect a gene by the biosensor technique is less than thirty minutes, while agarose gel electrophoresis needs more than one hour. Particularly, our electrochemical detection was more sensitive than the 
electrophoresis method because it was able to detect the RAGE gene at the lowest level of 10 copies, whereas the gel electrophoresis method was able to detect the RAGE gene only at concentrations of at least $10^{6}$ copies as far as the linearity for semi-quantitative measurement was concerned. This particular technique is sensitive, inexpensive, rapid and simple to use because it does not require specific skill. Nevertheless, it requires a clearly specific PCR band, because any non-specific PCR band can interfere with the electrochemical signal. Therefore, specific primers are needed for PCR amplification. For the RAGE gene, design of specific primers was rather difficult because it has many variants (Hudson et al., 2008), thus limiting the design for the appropriate length of the amplification product and selection for the A-T rich region. In addition, we attempted to optimize PCR amplification for both $\beta$-actin and the RAGE gene until we achieved the best result for each of them. In this study, PCR was performed with 30 cycles, which was effective in avoiding PCR saturation. To increase the efficiency of the electrochemical biosensor using Hoechst 33258, the electrode should be modified from carbon to gold (Hashimoto et al., 1994), though this will increase the cost. In conclusion, the electrochemical method can be used for semi-quantitative detection of gene expression and can be adapted for the rapid screening of many genes including the lowly expressed genes of interest.

\section{ACKNOWLEDGMENTS}

Research supported by grants provided by the Asahi Glass Foundation and the Chulalongkorn University Centenary Academic Development Project. P. Kittimongkolsuk received tuition fee scholarship from the Graduate School and a teaching assistant fellowship from the Faculty of Allied Health Sciences, Chulalongkorn University. The authors wish to thank Teerapong Lertwittayapon and Varaporn Rakkhittawatthana for their generous supplies of bacteria containing plasmid constructs carrying RAGE and $\beta$-actin, respectively.

\section{REFERENCES}

Ahmed MU, Idegami K, Chikae M, Kerman K, et al. (2007). Electrochemical DNA biosensor using a disposable electrochemical printed (DEP) chip for the detection of SNPs from unpurified PCR amplicons. Analyst 132: 431-438.

Ahmed MU, Hasan Q, Hossain MM, Saito M, et al. (2010). Meat species identification based on the loop mediated isothermal amplification and electrochemical DNA sensor. Food Control 21: 599-605.

Bernard PS and Wittwer CT (2002). Real-time PCR technology for cancer diagnostics. Clin. Chem. 48: 1178-1185.

Chaumpluk P, Chikae M, Takamura Y and Tamiya E (2006). Novel electrochemical identification and semi quantification of bovine constituents in feedstuffs. Sci. Tech. Adv. Mat. 7: 263-269.

Embrey KJ, Searle MS and Craik DJ (1993). Interaction of Hoechst 33258 with the minor groove of the A + T-rich DNA duplex d(GGTAATTACC)2 studied in solution by NMR spectroscopy. Eur. J. Biochem. 211: 437-447.

Fisker S, Hansen B, Fuglsang J, Kristensen K, et al. (2004). Gene expression of the GH receptor in subcutaneous and intraabdominal fat in healthy females: relationship to GH-binding protein. Eur. J. Endocrinol. 150: 773-777.

Hashimoto K, Ito K and Ishimori Y (1994). Sequence-specific gene detection with a gold electrode modified with DNA probes and an electrochemically active dye. Anal. Chem. 66: 3830-3833.

Horaková-Brazdilova P, Fojtova M, Vytras K and Fojta M (2008). Enzyme-Linked Electrochemical Detection of PCRAmplified Nucleotide Sequences Using Disposable Screen-Printed Sensors. Applications in Gene Expression Monitoring. Sensors 8: 193-210.

Hudson BI, Carter AM, Harja E, Kalea AZ, et al. (2008). Identification, classification, and expression of RAGE gene splice variants. FASEB J. 22: 1572-1580.

Kobayashi M, Kusakawa T, Saito M, Kaji S, et al. (2004). Electrochemical DNA quantification based on aggregation induced by Hoechst 33258. Electrochem. Commun. 6: 337-343.

Latt SA and Stetten G (1976). Spectral studies on 33258 Hoechst and related bisbenzimidazole dyes useful for fluorescent 
detection of deoxyribonucleic acid synthesis. J. Histochem. Cytochem. 24: 24-33.

Lertwittayapon T (2010). Cloning of Soluble Receptor for Advanced Glycation Endproducts (sRAGE) Gene and Study the Effect of its Expressed Product on Liver Cancer Cell. Master's thesis. Chulalongkorn Uninversity, Bangkok.

Nagaev I and Smith U (2001). Insulin resistance and type 2 diabetes are not related to resistin expression in human fat cells or skeletal muscle. Biochem. Biophys. Res. Commun. 285: 561-564.

Scheller FW, Wollenberger U, Warsinke A and Lisdat F (2001). Research and development in biosensors. Curr. Opin. Biotechnol. 12: 35-40.

Schmidt AM, Yan SD, Yan SF and Stern DM (2001). The multiligand receptor RAGE as a progression factor amplifying immune and inflammatory responses. J. Clin. Invest. 108: 949-955.

Stern DM, Yan SD, Yan SF and Schmidt AM (2002). Receptor for advanced glycation endproducts (RAGE) and the complications of diabetes. Ageing Res. Rev. 1: 1-15.

Sufen W, Tuzhi P and Yang CF (2002). Electrochemical studies for the interaction of DNA with an Irreversible redox compound-Hoechst 33258. Electroanalysis 14: 1648-1653.

Zhang FL, Gao HQ and Shen L (2007). Inhibitory effect of GSPE on RAGE expression induced by advanced glycation end products in endothelial cells. J. Cardiovasc. Pharmacol. 50: 434-440. 